\title{
Field Lysimeter Test Facility for Protective Barriers: Experimental Plan
}

\author{
R. R. Kirkham \\ G. W. Gee \\ J. L. Downs
}

December 1987

Prepared for the U.S. Department of Energy under Contract DE-AC06-76RLO 1830

Pacific Northwest Laboratory Operated for the U.S. Department of Energy by Battelle Memorial Institute 


\title{
DISCLAIMER
}

This report was prepared as an account of work sponsored by an agency of the United States Government. Neither the United States Government nor any agency thereof, nor Battelle Memorial Institute, nor any of their employees, makes any warranty, expressed or implied, or assumes any legal liability or responsibility for the accuracy, completeness, or usefulness of any information, apparatus, product, or process disclosed, or represents that its use would not infringe privately owned rights. Reference herein to any specific commercial product, process, or service by trade name, trademark, manufacturer, or otherwise, does not necessarily constitute or imply its endorsement, recommendation, or favoring by the United States Government of any agency thereof, or Battelle Memorial Institute. The views and opinions of authors expressed herein do not necessarly state or reflect those of the United States Government or any agency thereof, or Battelle Memorial Institute.

\author{
PACIFIC NORTHWEST LABORATORY \\ operated by \\ BATTELLE MEMORIAL INSTITUTE \\ for the \\ UNITED STATES DEPARTMENT OF ENERGY \\ under Contract DE-AC06-76RLO 1830
}

\begin{tabular}{|c|c|}
\hline \multicolumn{2}{|c|}{$\begin{array}{l}\text { Printed in the United States of America } \\
\text { Available from } \\
\text { National Technical Information Service } \\
\text { United States Department of Commerce } \\
5285 \text { Port Royal Road } \\
\text { Springfield, Virginia } 22161\end{array}$} \\
\hline \multicolumn{2}{|c|}{$\begin{array}{l}\text { NTIS Price Codes } \\
\text { Microfiche A01 }\end{array}$} \\
\hline \multicolumn{2}{|c|}{ Printed Copy } \\
\hline Pages & $\begin{array}{l}\text { Price } \\
\text { Codes }\end{array}$ \\
\hline $001-025$ & $\mathrm{~A} 02$ \\
\hline $026-050$ & $\mathrm{~A} 03$ \\
\hline $051-075$ & A04 \\
\hline $076-100$ & A05 \\
\hline $101-125$ & A06 \\
\hline $126-150$ & A07 \\
\hline 151-175 & $\mathrm{A} 08$ \\
\hline $176-200$ & $\mathrm{~A} 09$ \\
\hline $201-225$ & A010 \\
\hline $226-250$ & A011 \\
\hline $251-275$ & A012 \\
\hline $276-300$ & A013 \\
\hline
\end{tabular}


FIELD LYSIMETER TEST FACILITY

FOR PROTECTIVE BARRIERS:

EXPERIMENTAL PLAN

R. R. Kirkham

G. W. Gee

J. L. Downs

December 1987

Prepared for

the U.S. Department of Energy

under Contract DE-AC06-76RLO 1830

Pacific Northwest Laboratory

Richland, Washington 99352 
. 


\section{PREFACE}

This document was first written in October 1986 and has been used to guide the design of the Field Lysimeter Test Facility (FLTF) and to promote discussions between research and engineering staff regarding the selection of barrier treatments for inclusion in the FLTF. The construction of the lysimeter facility was completed June 28,1987 . This document describes the facility, the treatments placed in each lysimeter, types of measurements made in each lysimeter, and a brief discussion of project activities related to quality assurance, safety, and funding requirements. The treatment description and figures have been updated to reflect the lysimeter facility as constructed. An "as built" document describing in detail the backfilling activities and material properties is being prepared and will be published in 1988. 



\section{EXECUTIVE SUMMARY}

The Pacific Northwest Laboratory and Westinghouse Hanford Company have developed a Field Lysimeter Test Facility (FLTF) to test selected protective barrier designs. The effectiveness of the barriers for minimizing water infiltration will be examined under a variety of environmental conditions. Environmental variables include climate (precipitation), vegetation cover (evapotranspiration), surface admix (erosion control), and soil thickness. The FLTF is located on the Hanford Site just outside the 200 West Area and near the Hanford Meteorological Station.

Eighteen lysimeters (14 drainage-type and 4 weighing-type) are under construction. These lysimeters will be filled with candidate soil and rock materials that may be used as protective barriers over waste disposal sites. Laboratory analyses will be conducted to evaluate the physical characteristics of these materials as related to water infiltration and storage. Orainage will be measured from each of the lysimeters. The estimated precision of the drainage measurement is $\$ 0.04 \mathrm{~cm} / \mathrm{yr}$. Water storage and evapotranspiration components of the water balance will also be monitored using gamma probes, neutron probes, and direct weighing. The estimated precision for evapotranspiration and water storage measurements ranges from $\pm 0.04 \mathrm{~cm}$ for weighing lysimeter measurements to $\pm 1.6 \mathrm{~cm}$ for neutron probe measurements. Additionally, information on soil water potential and soil temperature will be collected. These data sets will be used to calibrate models that will assist in predicting longterm $(10,000$ year) barrier performance.

Climate (precipitation) changes will be simulated by evaluating barrier performance at normal, twice normal, and precipitation-to-failure conditions. water loss from the barrier system is through evapotranspiration. The impacts of vegetation, bare soil, and gravel admix (erosion control) on evapotranspiration will be evaluated. To date, the FLTF is the largest lysimeter facility at Hanford constructed with U.S. Department of Energy funds. The FLTF is the primary research tool of the barrier program; information collected at the FLTF will be of interest to many other organizations dealing with isolation of hazardous waste in arid climates. 



\section{CONTENTS}

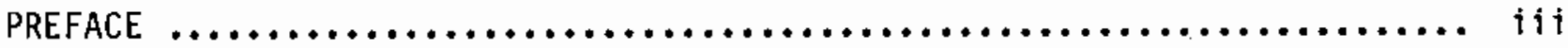

EXECUTIVE SUMMARY $\ldots \ldots \ldots \ldots \ldots \ldots \ldots \ldots \ldots \ldots \ldots \ldots \ldots \ldots \ldots \ldots \ldots \ldots \ldots \ldots \ldots$

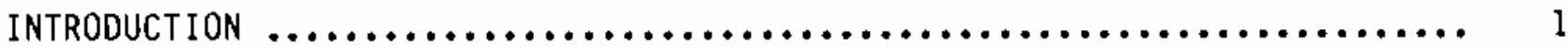

DESCRIPTION OF THE FACILITY $\ldots \ldots \ldots \ldots \ldots \ldots \ldots \ldots \ldots \ldots \ldots \ldots \ldots \ldots \ldots \ldots \ldots \ldots \ldots$

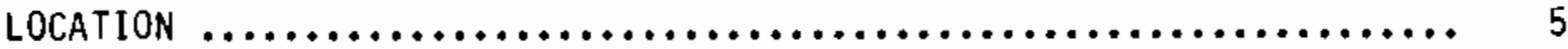

FIELD LYSIMETER DESIGN $\ldots \ldots \ldots \ldots \ldots \ldots \ldots \ldots \ldots \ldots \ldots \ldots \ldots \ldots \ldots \ldots$

BARRIER TREATMENTS AND MATERIALS $\ldots \ldots \ldots \ldots \ldots \ldots \ldots \ldots \ldots \ldots \ldots \ldots \ldots$

Treatment 1: Fine Soil, Normal Precipitation, and

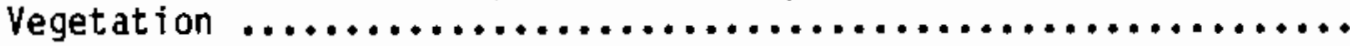

Treatment 2: Fine Soil, Normal Precipitation, No

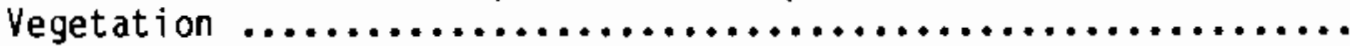

Treatment 3: Fine Soil, Double Precipitation, and

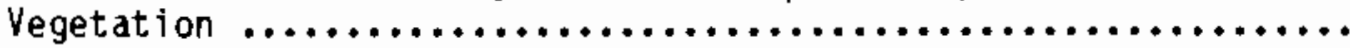

Treatment 4: Fine Soil, Double Precipitation, and No Vegetation

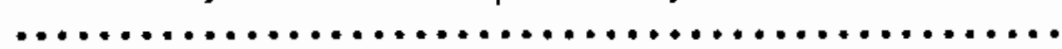

Treatment 5: Fine Soil with Surface Gravel Admix, Normal Precipitation, and Vegetation

Treatment 6: Fine Soil 1.0-m Thick, Normal Precipitation, and Vegetation

Treatment 7: Fine Soil, Precipitation to Failure, and No Vegetation.

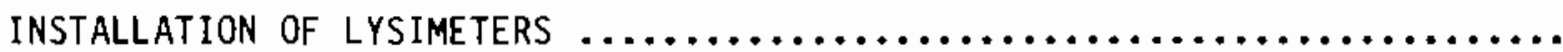

INSTRUMENTATION REQUIREMENTS AND INSTALLATION $\ldots \ldots \ldots \ldots \ldots \ldots \ldots \ldots \ldots . \ldots 22$

INSTRUMENTATION AND MEASUREMENT TECHNIQUES $\ldots \ldots \ldots \ldots \ldots \ldots \ldots \ldots \ldots \ldots \ldots \ldots$

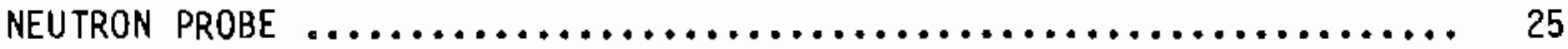

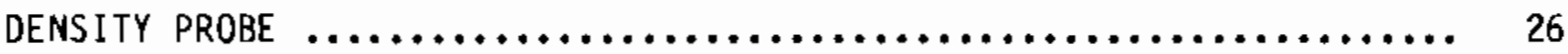

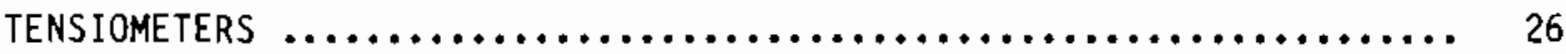

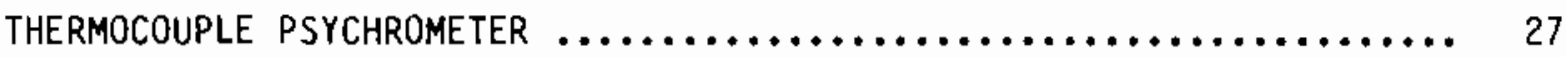


THERMOCOUPLES $\ldots \ldots \ldots \ldots \ldots \ldots \ldots \ldots \ldots \ldots \ldots \ldots \ldots \ldots \ldots \ldots \ldots \ldots, 27$

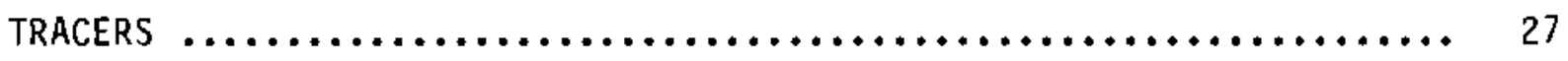

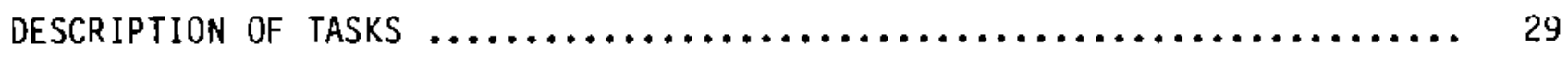

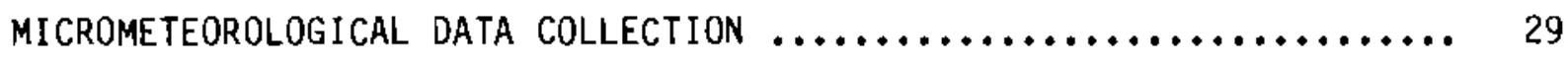

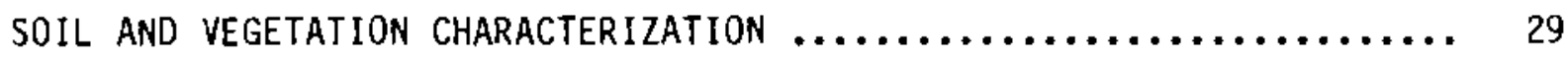

PRECIPITATION ENHANCEMENT STUDIES $\ldots \ldots \ldots \ldots \ldots \ldots \ldots \ldots \ldots \ldots \ldots \ldots, 30$

MANPOWER AND MATERIAL ESTIMATES $\ldots \ldots \ldots \ldots \ldots \ldots \ldots \ldots \ldots \ldots \ldots, 32$

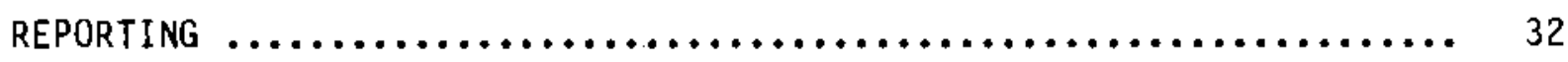

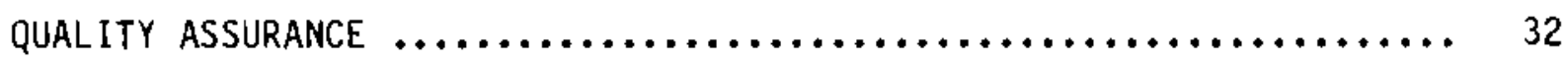

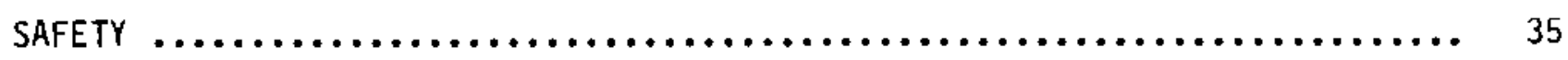

EXPECTED RESULTS AND CONCLUSTONS $\ldots \ldots \ldots \ldots \ldots \ldots \ldots \ldots \ldots \ldots \ldots \ldots \ldots . \ldots \ldots \ldots$

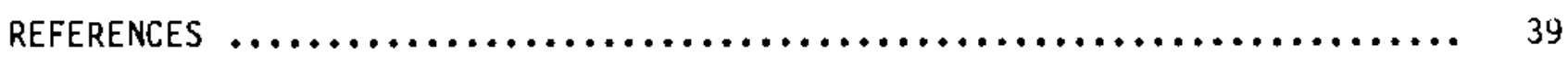




\section{FIGURES}

1 Location of the FLTF at the Hanford Site $\ldots \ldots \ldots \ldots \ldots \ldots \ldots \ldots \ldots \ldots$

2 Schematic Drawing of the FLIF Showing One Half of the Parallel Configuration of Lysimeters ............................. 7

3 Plan View for the FLTF $\ldots \ldots \ldots \ldots \ldots \ldots \ldots \ldots \ldots \ldots \ldots \ldots \ldots \ldots \ldots \ldots$

4 Drainage Lysimeter Construction, Top and Side Views ............. 9

5 Weighing Lysimeter Construction, Top and Side Views ............. 10

6 Cutaway Schematic of Drainage Lysimeter Showing Rock and Soi 1 Layers and Instrument Placement ........................... 11

\section{TABLES}

1 Proposed Barrier Treatments Using 18 Lysimeters Located at

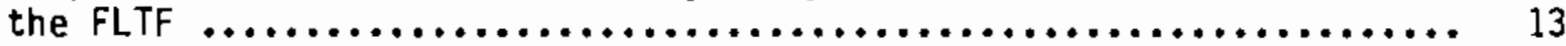

2 List of Parameters to be Measured at the FLTF . ................ 23

3 Expected Measurement Precision for Water-Balance Components of Drainage, Storage, Evapotranspiration, and Precipitation .......... 24

4 Projected Operational Expenditures for FY 1988 Through FY $1992 \ldots \ldots$

5 Quality-Controlled Instruments: Calibration and Operation ......... 33 



\section{INTRODUCTION}

Protective barriers over waste sites have been proposed as an engineering alternative to exhuming wastes and relocating them. These protective barriers can limit plant and animat intrusion and at the same time minimize water infiltration thereby providing long-term protection of the underlying wastes. Protective barriers will be an essential tool in isolating near-surface buried waste from the environment. By controlling infiltration of water, these barriers also control the release and subsequent transport of radionuclides to groundwater. The Interim Hanford Waste Management Technology Plan (USDOE-RL 1986) identifies the potential need for protective barriers for grouted lowactivity waste removed from double-shell tank farms, single-shell tank farms, contaminated-soil sites, and solid-waste burial sites. These sites must be controlled for periods extending from hundreds of years to beyond 10,000 years without active monitoring, maintenance, or active institutional controls.

Westinghouse Hanford Company (WHC) is formulating barrier performance standards based on needs specified in the Draft Hanford Defense Waste Environmental Impact Statement (USDOE 1986). Important technical considerations include selecting, evaluating, and demonstrating barrier materials, barrier systems, and emplacement methods that will meet the requirements of the U.S. Department of Energy (DOE), U.S. Environmental Protection Agency, and Washington State. To address these concerns, a protective barrier program was established for the Hanford site.

The Hanford Site Protective Barrier Development Program was developed jointly by WHC and the Pacific Northwest Laboratory (PNL) with objectives to test barrier design concepts and to select a "proven" barrier design for implementation. During this selection process, there will be a thorough field testing of specific barrier designs using lysimeters and small- and large-scale fieid plots. These tests will provide data for direct comparison of key barrier components. In addition, specific data sets will be used to calibrate and test models that will accurately predict long-term barrier performance.

The barrier program addresses specific issues related to barrier design and performance. The program tasks include assessments of 1) biointrusion 
control, 2) water infiltration control, 3) erosion control, 4) barrier construction materials, 5) physical stabilization (subsidence), 6) human intrusion control, 7) field monitoring and model validation, 8) natural analogs, and 9) climate change effects. In addition, interactions between environmental and design factors that may cause disruption or degradation of the barrier are also addressed. Specifically, the effects of biointrusion on water infiltration will be studied, as well as the effects of erosion control (i.e., surface gravel additions) on plant growth and water infiltration and storage. These program tasks are presented in detail in the Protective Barrier and Warning Marker System Development Plan (Adams and Wing 1986).

The amount of yearly precipitation not removed by evapotranspiration and available to move through waste sites at Hanford is at present unknown. However, calculations made in the Draft Hanford Defense Waste Environmental Impact Statement (USDDE 1986) indicate that only a small amount of water $(<0.1 \mathrm{~cm} / \mathrm{yr}$ ) can move through the waste without potentially causing the appearance of radionuclides in the groundwater. It appears that the feasibility of in-place disposal of waste at Hanford could rest (in the absence of a high-integrity waste form) with providing barriers that ensure a near-zero drainage rate for extended periods of time. This requirement is stringent and suggests that strict barrier performance standards may be required.

The Field Lysimeter Test Facility (FLTF), designed to evaluate water infiltration aspects of barrier performance, was completed June 30, 1987. This report describes the test plan for the FLTF and the infiltration tests and measurement techniques to be performed that will aid in evaluating barrier designs. These designs must meet specified drainage or recharge limits. This test plan also describes the lysimeter configurations, the monitoring scheme for the iysimeters, estimates of the accuracy of the measurements, and a rationale for the specific tests proposed.

Lysimeters will allow direct measurement of any water that passes through the barrier system being tested. Using this collected water, we can accurately measure the effectiveness of the barrier system under the environmental conditions experienced during the observation period. The amounts of water collected from the lysimeters will be compared to performance criteria determined 
by our present understanding of the long-term risks associated with in-place disposal of wastes at the Hanford Site. Although the performance criteria are based on an approximation of expected barrier performance, the assessment reflects the present understanding of the most likely source term and pathways for the specific system. An effective approach for evaluating infiltration control for long-term barrier performance is to couple short-term data with model simulations. The short-term data will be used to calibrate the model, and the calibrated model will be used to predict long-term barrier performance. The test facility was designed so that barriers are tested under conditions of normal and enhanced precipitation and bare and vegetated surfaces.

Although the main objective of the lysimeter facility is to assess the effectiveness of selected protective barrier designs in controlling water infiltration, it will also be used to evaluate the impact of selected engineering changes in the barriers, such as the assessment of varying the soil thickness and adding gravel at the soil surface. Results from the lysimeter facility will be used in determining a final barrier design. Using gravel to control erosion is one of the current design features that will require testing to assess its impact on the overall effectiveness of the system.

A description of the facility, its location, and the field lysimeters, as well as details on the installation of the lysimeter and use, are contained in this report. Information on cost, schedule, safety, and quality assurance is also included. 


\section{DESCRIPTION OF THE FACILITY}

LOCATION

The FLTF is located on the Hanford Site near the Hanford Meteorological Station (HMS) between the 200-West and 200-East Areas (Figure 1). The facility is approximately $150 \mathrm{~m}$ west-southwest of the main instrument tower at the HMS. The site was chosen because of its proximity to the major waste management areas (200 East and 200 West) at Hanford and the quality-assured climate data that are available at the HMS.

\section{FIELD LYSIMETER DESIGN}

Pacific Northwest Laboratory and WHC staff developed a conceptual design of the FLTF and worked with Kaiser Engineers of Hanford to finalize the design. This facility will be used as both a research and demonstration facility for the barrier program. The FLTF is constructed from a parallel set of steel tanks buried at grade. The tanks are fabricated from $1 / 4 \mathrm{in}$. steel plate and reinforced as needed. Figure 2 shows a perspective drawing of one half of the FLTF. Figures 3 through 5 illustrate the overall design features.

The FLTF contains both drainage- and weighing-type lysimeters. The measurement capabilities of these two lysimeter types were described previously (Gee and Jones 1985) and appear to be suitable to test barrier performance for water infiltration control. The drainage lysimeters (DL) are designed to contain a barrier with a fixed volume (2-m dia $\times 3-m$ deep) in which storage changes are measured using a neutron probe, a gamma probe, and periodic sampling. Drainage is measured directly by collecting water from a drain port at the bottom of the lysimeter (Figure 6 ). The weighing lysimeters (WL) isolate a soil volume $(1.5 \mathrm{~m} \times 1.5 \mathrm{~m} \times 1.5 \mathrm{~m})$ and generate a continual record of weight changes, which, when supplemented with physical observations, can be used to estimate precipitation, evaporation, and storage changes. In addition, a direct measurement of drainage is made by collecting water from a drain port at the bottom of the lysimeter. 


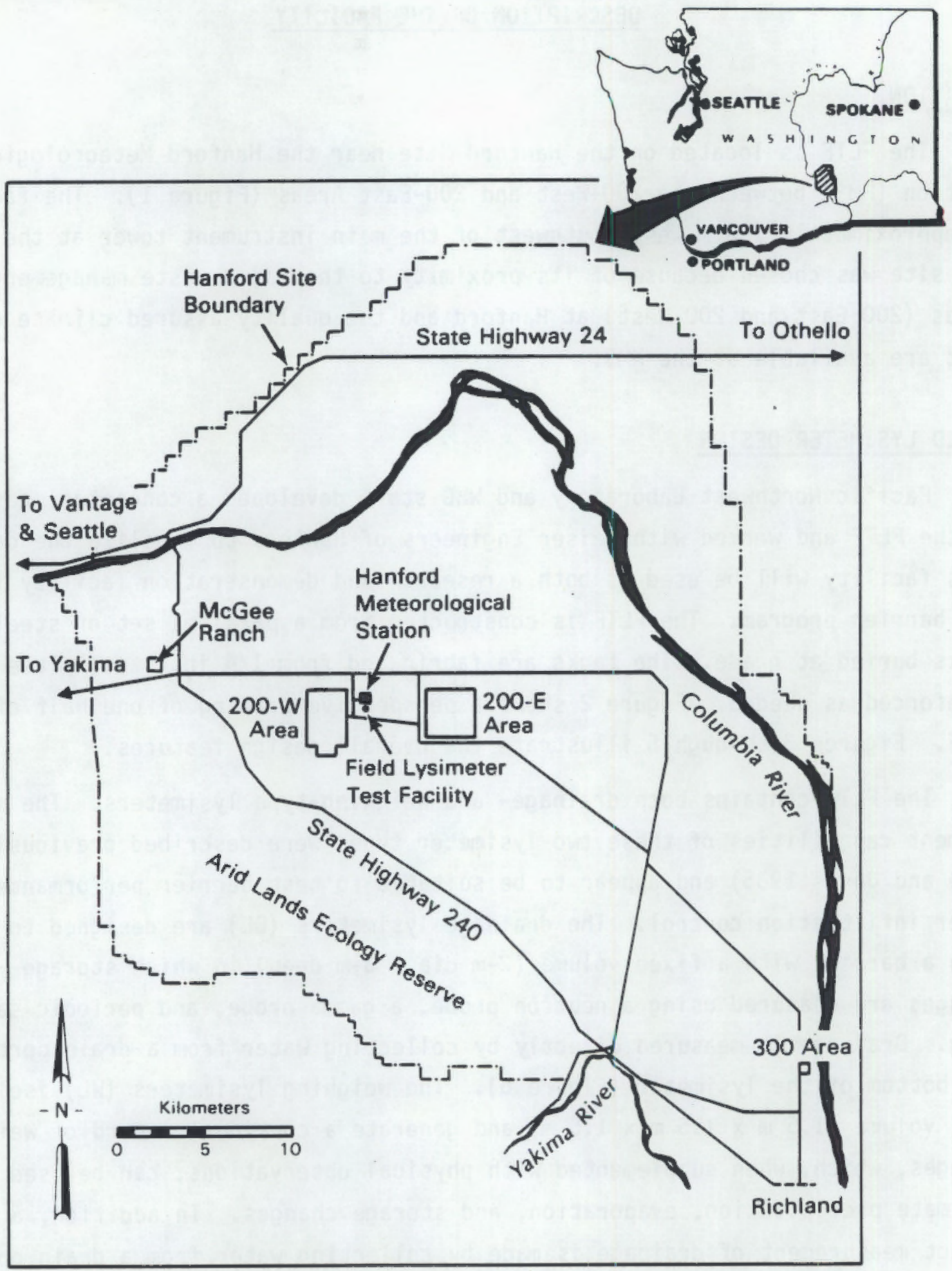

FIGURE 1. Location of the FLTF at the Hanford Site 


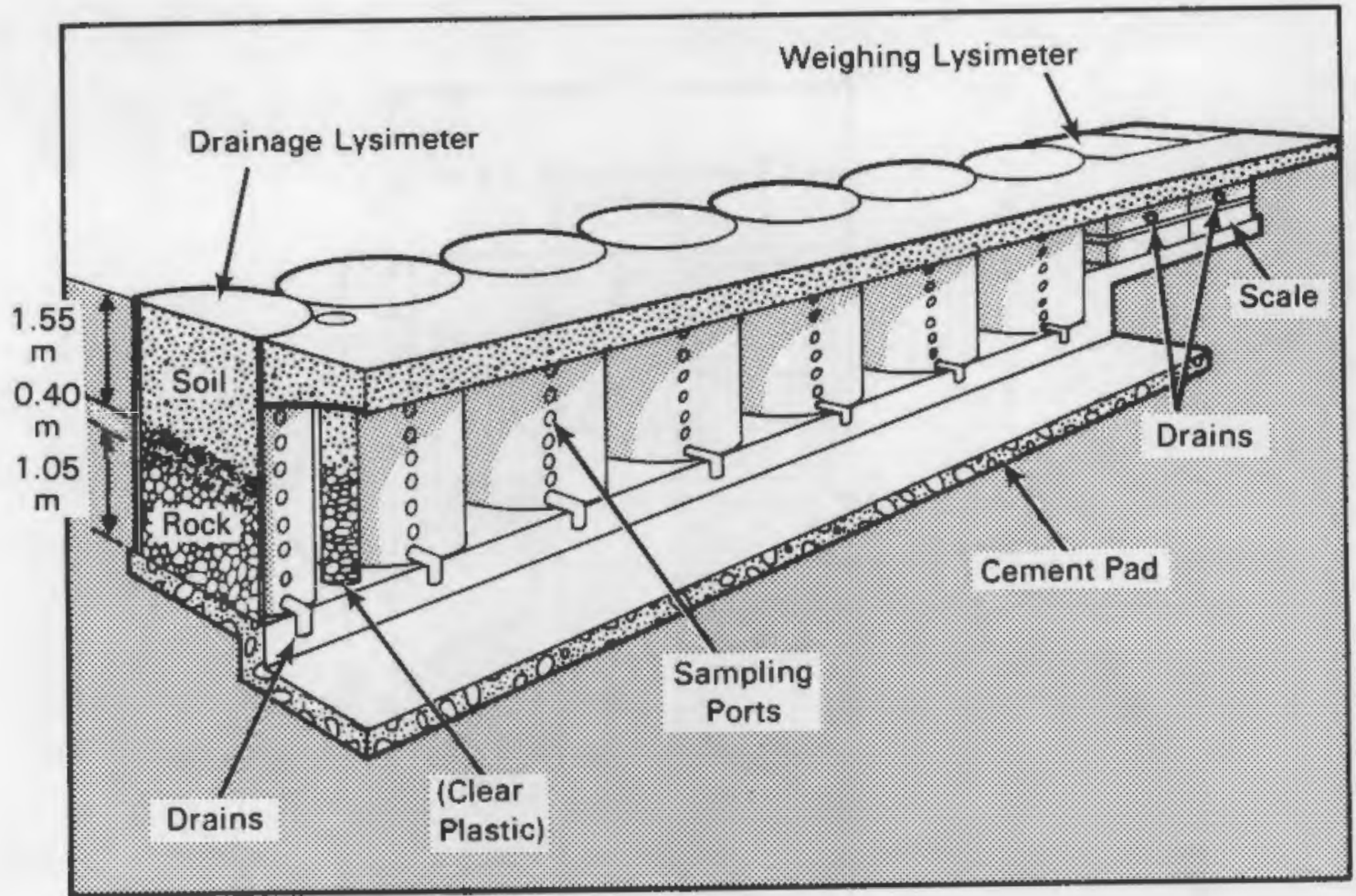

FIGURE 2. Schematic Drawing of the FLTF Showing One Half of the Parallel Configuration of Lysimeters

\section{BARRIER TREATMENTS AND MATERIALS}

The barrier systems to be tested in the FLTF were selected to 1) demonstrate the effectiveness of a multilayer barrier for using a pore-size discontinuity to limit unsaturated flow, 2) collect information on barrier performance under natural and elevated rainfall conditions, and 3) examine effects of vegetation on barrier performance.

Precipitation [the amount of water (rain or snow) added to the soil profile] and evapotranspiration (the amount of water removed through bare soil evaporation and plant transpiration) at the surface of the barrier system are inputs and outputs, respectively. When precipitation $(P)$ is larger than evapotranspiration (ET), soil water storage increases, and, conversely, when ET is larger than P, soil water decreases. The amount of water that can be stored is directly related to depth of the soil and its physical characteristics, such as texture and layering. 


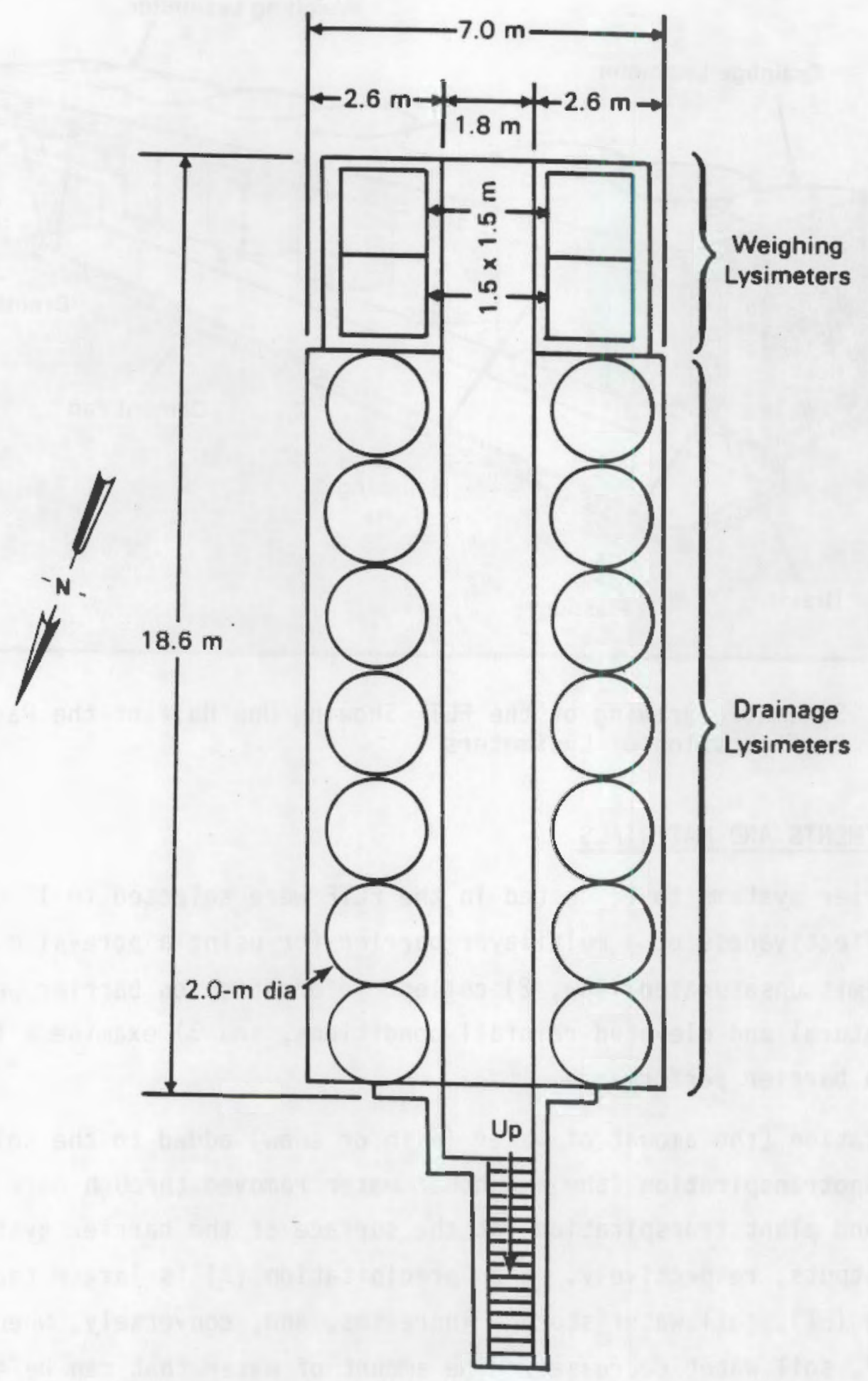

FIGURE 3. Plan View for the FLTF 


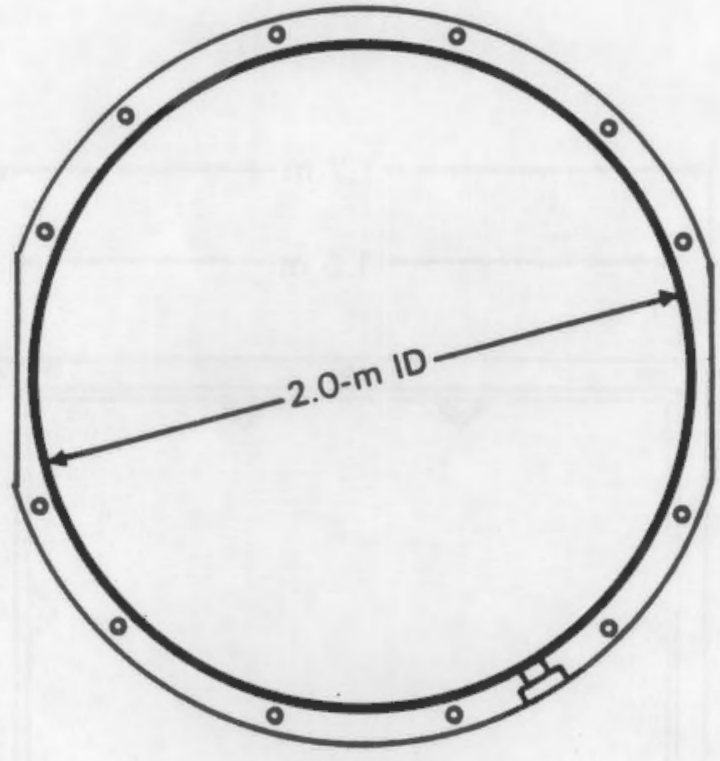

Top View

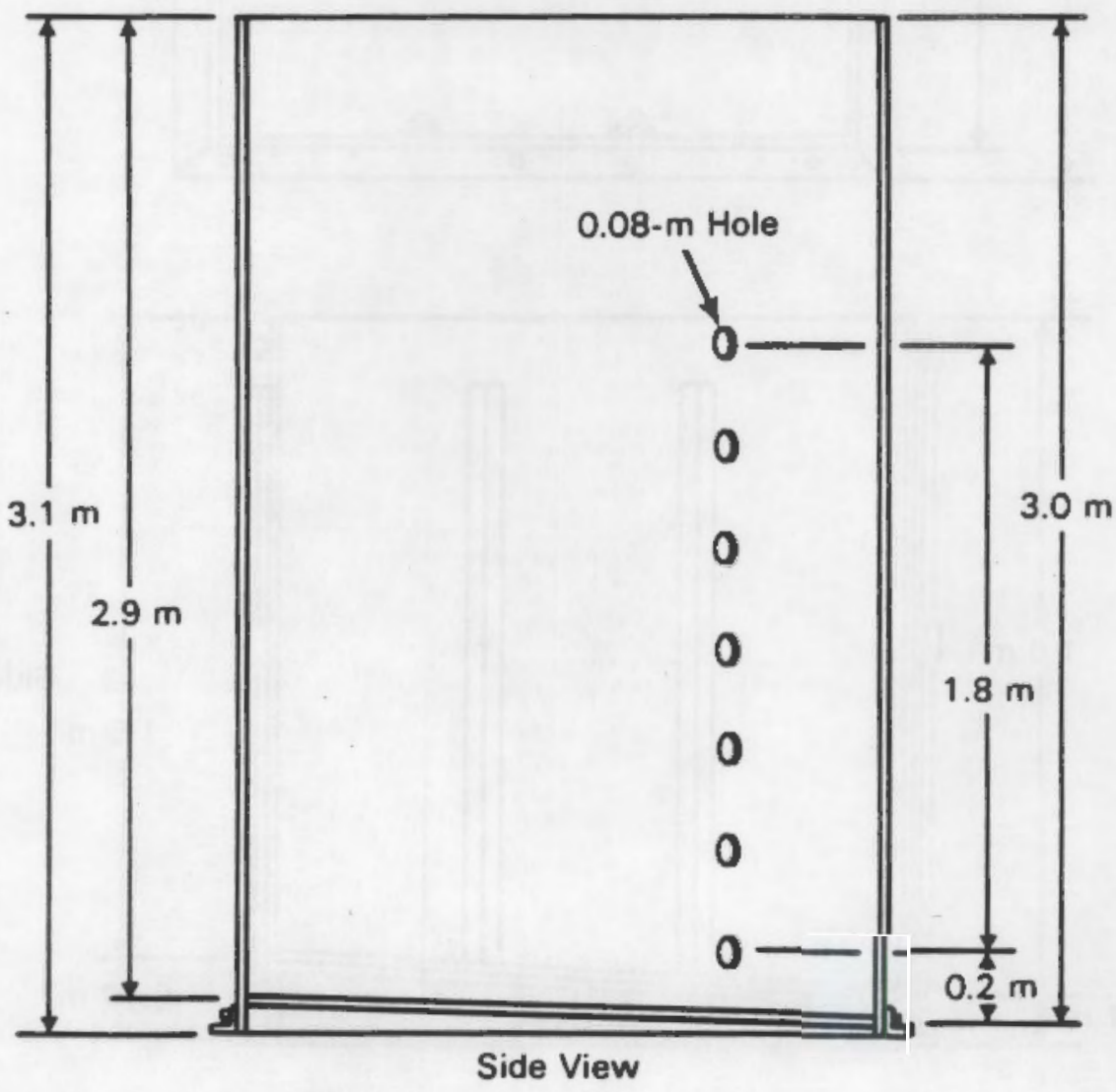

F IGURE 4. Drainage Lysimeter Construction, Top and Side Views 

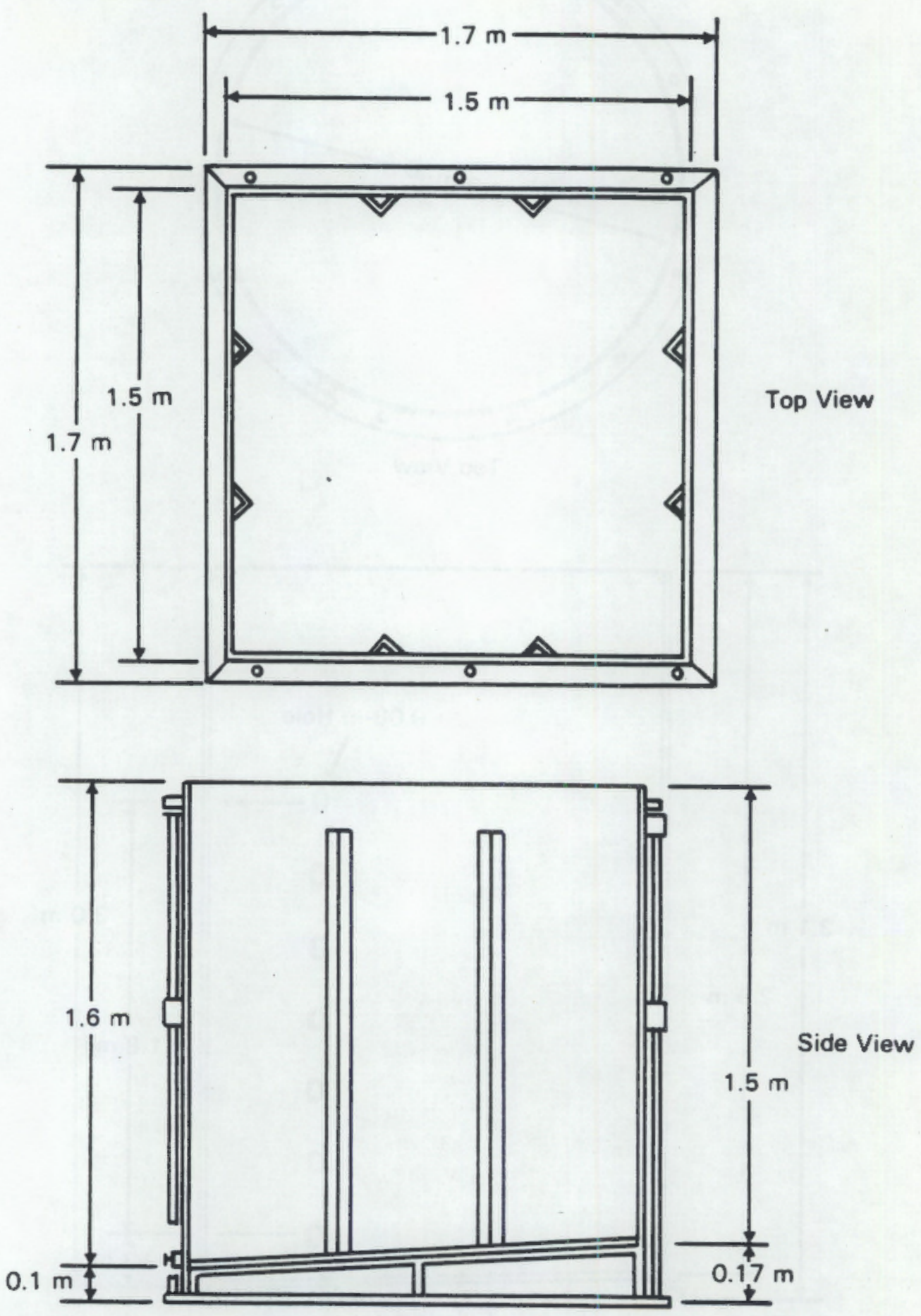

FIGURE 5. Weighing Lysimeter Construction, Top and Side Views 


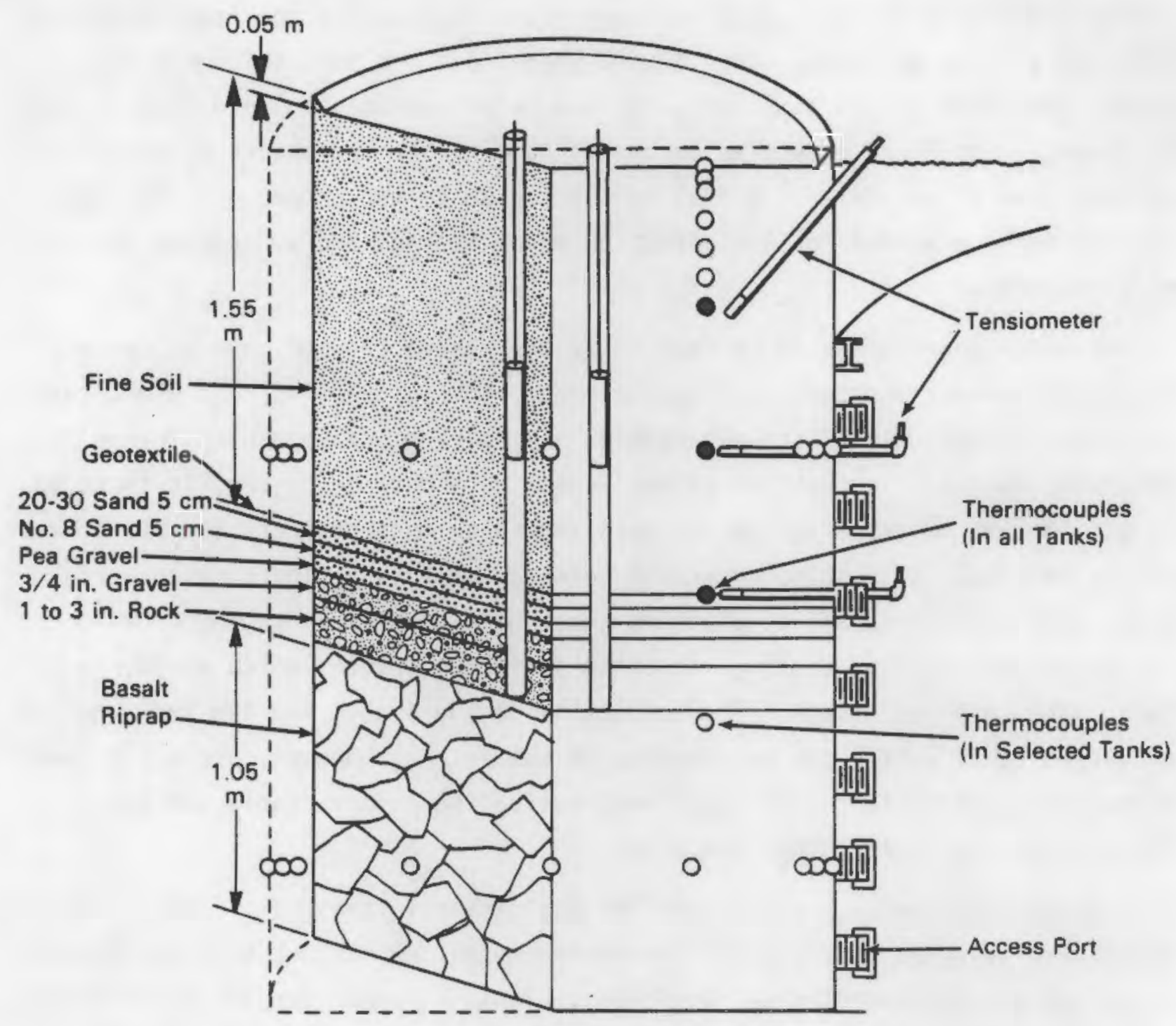

FIGURE 6. Cutaway Schematic of Drainage Lysimeter Showing Rock and Soil Layers and Instrument Placement

Adequate soil thickness is important for the barrier system to operate effectively. If the soil layer thickness is insufficient to store yearly precipitation, the soil at the bottom of the soil layer may saturate and drain into lower rock layers. Additionally, if the soil layer is too thick, water may move below the root zone and eventually cause saturation at the bottom of 
the interface and subsequent drainage. For typical arid site conditions, the depth of soil that will be effective is thought to be between 1 and $2 \mathrm{~m}$. Preliminary modeling efforts using characteristics for a silt loam soil indicate $1.5 \mathrm{~m}$ of soil as suitable. Over 10,000 years, a 1.5-m soil thickness may erode; therefore, a $1-m$ soil depth is also being examined to determine if this thickness is still an effective barrier. To minimize the chance of erosion, the addition of an admix of gravel in the top $20 \mathrm{~cm}$ was proposed. This admix is also being examined for its effect on water storage and subsequent barrier effectiveness.

Barrier performance is controlled by the interaction of several dynamic and static processes associated with climate, soil properties, and plant cover characteristics. All of these variables have a range of possible, rather than discrete, values. To test the effectiveness of a barrier system, it is necessary to select discrete values for each variable, then evaluate the performance of the barrier. It is also important to note the interaction between variables, such as increased precipitation causing increased plant growth or increased gravel cover causing increased surface moisture, which would, in turn, enhance plant growth. The complexity of the system and the large number of variables affecting the performance of the system, however, prevent a complete and accurate factorial experiment evaluating each variable and its interaction with every other variable.

Seven treatments were selected for evaluation in the FLTF. These treatments were selected to represent the environmental conditions most likely to occur and possible worst-case conditions. Table 1 summarizes the seven treatments associated with the 18 lysimeters at the FLTF. Four of the seven treatments will be used in a $2 \times 2$ factorial design to examine the main effects of precipitation (normal and 2 times normal) and soil cover [no vegetation (bare soil) and vegetation]. These four treatments are replicated twice in drainage lysimeters and once in weighing lysimeters using a total of 12 lysimeters. Two additional main-effect treatments (using 4 additional lysimeters), with other variables held constant, will consist of 1) a comparison of bare soil with a soil containing $15 \%$ gravel by weight in the top $20 \mathrm{~cm}$ and 2) a comparison of a 
IABLE 1. Proposed Barrier Treatments Using 18 Lysimeters Located at the FLTF

\begin{tabular}{|c|c|c|c|c|c|c|c|c|}
\hline \multirow[b]{2}{*}{ Treatment } & \multicolumn{3}{|c|}{ Precipitation } & \multicolumn{3}{|c|}{ Surface } & \multicolumn{2}{|c|}{$\begin{array}{l}\text { Soil } \\
\text { Thickness }\end{array}$} \\
\hline & $N(a)$ & $2 N^{(b)}$ & Sat & Bare & Veg & Admix & $1.0 \mathrm{~m}$ & $1.5 \mathrm{~m}$ \\
\hline 1 & $x$ & & & & $x$ & & & $x$ \\
\hline 2 & $x$ & & & $x$ & & & & $x$ \\
\hline 3 & & $x$ & & & $x$ & & & $x$ \\
\hline 4 & & $x$ & & $x$ & & & & $x$ \\
\hline 5 & $x$ & & & & $x$ & $x$ & & $x$ \\
\hline 6 & $x$ & & & & $x$ & & $x$ & \\
\hline 7 & & & $x$ & $x$ & & & & $x$ \\
\hline
\end{tabular}

(a) Normal precipitation.

(b) Twice normal precipitation.

1.0- versus $1.5-m$-thick soil profile. A seventh treatment (using 2 lysimeters) will be used to study the behavior of a barrier system when sufficient water is applied to cause failure. This treatment will be used for short-term experiments to determine soil hydraulic conductivities and field capacity. After short-term tests are completed, vegetation will be seeded and transplanted on the two lysimeters to indicate how rapidly these plants establish themselves and use the water in a very wet profile. The time required to return soi 1 water storage to levels equal to the normal precipitation treatment will also be determined. A discussion of each treatment (including the objective), layer sequence, and suggested sensor locations in the drainage lysimeters follows. Sensors currently planned for installation include thermocouples and thermocouple psychrometers. (Instrumentation is discussed in more detail in a later section.) The lysimeters have been designed to facilitate the addition of instrumentation at a later date, if necessary.

Treatment 1: Fine Soil, Normal Precipitation, and Vegetation

This treatment represents a barrier design that incorporates features of adequate soil-water storage capacity and optimizes water loss via evapotranspiration processes. This barrier system will evaluate $1.5 \mathrm{~m}$ of fine soil to store water under normal precipitation conditions with surface vegetation that 
will increase evapotranspirational losses. The treatment will serve as the primary demonstration of the effectiveness of the barrier design.

Replication: 2 drainage lysimeters and 1 weighing lysimeter.

Material Layers

Surface - Seed and transplant vegetation

$0.05^{(a)}$ to $1.55 \mathrm{~m}$ - soil backfill from McGee Ranch

$1.55 \mathrm{~m}$ - geotextile mat

1.55 to $1.95 \mathrm{~m}$ - sand and gravel layers

1.95 to $3.0 \mathrm{~m}$ - basalt riprap

Instrumentation

Neutron probe: measurements taken at depths of $0.15,0.30,0.45,0.60$, $0.75,0.90,1.20$, and $1.35 \mathrm{~m}$

Gamma probe: measurements taken at depths to be determined

Tensiometers: installed at depths of $0.5,1.0$, and $1.5 \mathrm{~m}$

Thermocouples: installed as indicated

Vertical $-0.50,1.0$, and $1.5 \mathrm{~m}$

Horizontal - 0.0 (inner tank walls), $0.05,0.10,0.5,1.0,1.5,1.9$, 1.95, and $2.0 \mathrm{~m}$ (outer tank wall) taken at depths of 0.5 and $2.5 \mathrm{~m}$

Rhizotron: lucite tubes for camera observation of root penetration

Treatment 2: Fine Soil, Normal Precipitation, No Vegetation

This treatment represents the optimized barrier design without vegetation, as presented in Treatment 1. Under normal precipitation levels, the barrier should function for several years even in the absence of vegetation. An actual barrier might see this condition only after range fires or extended droughts.

(a) The soil surface is $0.05 \mathrm{~m}$ below the top edge in all lysimeters to minimize runoff. All material layers are referenced to the top edge of the tank. All instrumentation and measurement locations are referenced to soil surface. 
Although this is a transient condition, the effect of no vegetation on water balance needs to be documented. Vegetation will be prevented from establishment by removing seedlings or using herbicides. Replication: 2 drainage lysimeters and 1 weighing lysimeter.

Material Layers

Surface - bare soil

0.05 to $1.55 \mathrm{~m}$ - soil backfill from McGee Ranch

$1.55 \mathrm{~m}$ - geotextile mat

1.55 to $1.95 \mathrm{~m}$ - sand and gravel layers

1.95 to $3.0 \mathrm{~m}$ - basalt riprap

Instrumentation

Neutron probe: measurements taken at depths of $0.15,0.30,0.45,0.60$, $0.75,0.90,1.20$, and $1.35 \mathrm{~m}$

Gamma probe: measurements taken at depths to be determined

Tensiometers: installed at depths of $0.5,1.0$, and $1.5 \mathrm{~m}$

Thermocouples: installed at depths of $0.5,1.0$, and $1.5 \mathrm{~m}$

Treatment 3: Fine Soil, Double Precipitation, and Vegetation

This treatment represents the same optimized barrier design presented in Treatment 1 , except the annual average precipitation is doubled. The vegetation will likely increase as the available water increases, but it will take several years for this vegetation to reach the actual total biomass that could be supported under heavy rainfall conditions. Replication: 2 drainage lysimeters and 1 weighing lysimeter.

\section{Material Layers}

Surface - seed and transplant vegetation

0.05 to $1.55 \mathrm{~m}$ - soil backfill from McGee Ranch

$1.55 \mathrm{~m}$ - geotextile mat

1.55 to $1.95 \mathrm{~m}$ - sand and gravel layers

1.95 to $3.0 \mathrm{~m}$ - basalt riprap 


\section{Instrument ation}

Neutron probe: measurements taken at depths of $0.15,0.30,0.45,0.60$, $0.75,0.90,1.20$, and $1.35 \mathrm{~m}$

Gamma probe: measurements taken at depths to be determined

Tensiometers: installed at depths of $0.5,1.0$, and $1.5 \mathrm{~m}$

Thermocouples: installed at depths of $0.5,1.0$, and $1.5 \mathrm{~m}$

Rhizotron: lucite tubes for camera observation of root penetration

Treatment 4: Fine SoiT, Double Precipitation, and No Vegetation

This is the worst-case condition applied to the barrier system. This treatment receives twice normal rainfall and has no plants to remove stored water. Under these conditions some drainage may occur. The elevated rainfali should cause this treatment to reach equilibrium conditions much faster than the natural rainfall treatments. The application rate of additional precipitation is discussed in a later section. Replication: 2 drainage lysimeters and 1 weighing lysimeter.

\section{Material Layers}

Surface - bare soil

0.05 to $1.55 \mathrm{~m}$ - soil backfill from McGee Ranch

$1.55 \mathrm{~m}$ - geotextile mat

1.55 to $1.95 \mathrm{~m}$ - sand and gravel layers

1.95 to 3.0 m - basalt riprap

Instrumentation

Neutron probe: measurements taken at depths of $0.15,0.30,0.45,0.60$, $0.75,0.90,1.20$, and $1.35 \mathrm{~m}$

Gamma probe: measurements taken at depths to be determined

Tensiometers: installed at depths of $0.5,1.0$, and $1.5 \mathrm{~m}$

Thermocouples: installed as indicated 


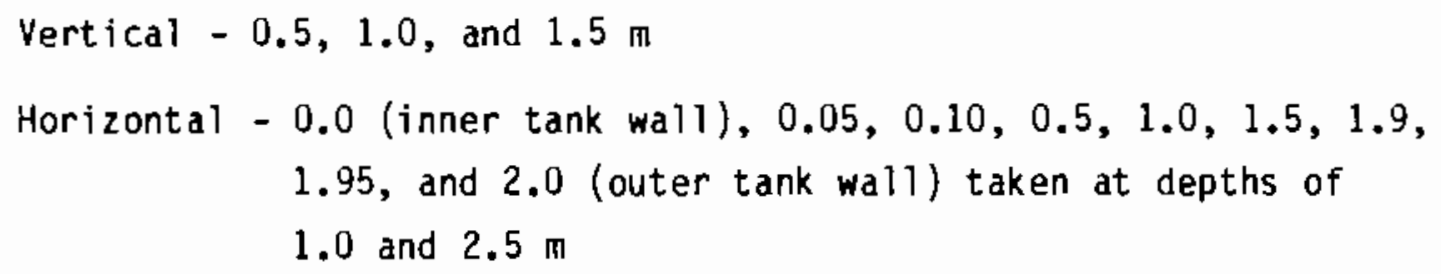

Treatment 5: Fine Soj l with Surface Gravel Admix, Normal Precipitation, and Vegetation

Treatment 5 is identical to Treatment 1 except the surface has gravel (15\% by weight in the top $20 \mathrm{~cm}$ ) incorporated to minimize erosion. This treatment is to determine whether surface gravel causes an unacceptable increase in water storage. Replication: 2 drainage lysimeters.

Material Layers

Surface - bare soil

0.05 to $0.15 \mathrm{~m}$ - soil and gravel mixture for erosion control

0.15 to $1.55 \mathrm{~m}$ - soil backfill from McGee Ranch

$1.55 \mathrm{~m}$ - geotextile mat

1.55 to 1.95 m - gravel interface

1.95 to $3.0 \mathrm{~m}$ - basalt riprap

Instrumentation

Neutron probe: measurements taken at depths of $0.15,0.30,0.45,0.60$, $0.75,0.90,1.20$, and $1.35 \mathrm{~m}$

Gamma probe: measurements taken at depths to be determined

Tensiometers: installed at depths of $0.5,1.0$, and $1.5 \mathrm{~m}$

Thermocouples: installed as indicated

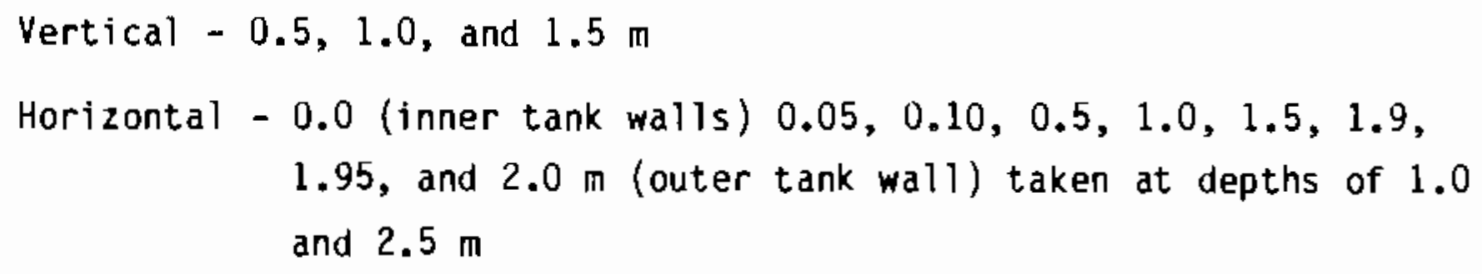


Treatment 6: Fine Soil 1.0-in Thick, Normal Precipitation, and Vegetation

This lysimeter will be used to evaluate the effect of the depth of the fine soil on barrier performance. Under certain environmental conditions, the soil surface may erode and reduce the soil available for water storage. The removal of $0.5 \mathrm{~m}$ of soil is felt to represent a severe erosion scenario for the 10,000-year operation of the barrier system. This treatment will help to demonstrate barrier performance at reduced soil thickness. Replication: 2 drainage lysimeters.

Material Layers

Surface - seed and transplant vegetation

0.05 to $1.05 \mathrm{~m}$ - soil backfill from McGee Ranch

$1.05 \mathrm{~m}$ - geotextile mat

1.05 to $1.45 \mathrm{~m}$ - sand and gravel layers

1.45 to $3.0 \mathrm{~m}$ - basalt riprap

Instrumentation

Neutron probe: measurements taken at depths of $0.15,0.30,0.45,0.60$, 0.75 , and $0.90 \mathrm{~m}$

Ganma probe: measurements taken at depths to be determined

Tensiometers: installed at depths of 0.5 and 1.0

Thermocouples: installed as indicated

$$
\begin{aligned}
& \text { Vertical }-0.5,1.0 \text {, and } 1.5 \mathrm{~m} \\
& \text { Horizontal }-0.0 \text { (inner tank walls), } 0.05,0.10,0.5,1.0,1.5,1.9 \text {, } \\
& \quad \begin{aligned}
1.95, \text { and } 2.0 \mathrm{~m} \text { (outer tank wall) taken at depths } 1.0 \\
\text { and } 2.5 \mathrm{~m}
\end{aligned}
\end{aligned}
$$

Treatment 7: Fine Soil, Precipitation to Failure, and No Vegetation (initially)

This treatment will be used to examine the physical behavior of the barrier system when enough water is added to the system to cause transmission of water through the barrier; initially evapotranspiration will be prevented. Data collected during wetting of the soil profile will be extremely useful for 
the model validation study. Collection of these data should be completed within a few months after the lysimeters are backfilled. After barrier failure is achieved, the lysimeter will be temporarily covered and in-place hydraulic conductivity measurements will be made by using observed moisture storage changes and measured water potential gradients (Klute 1972). As drainage becomes insignificant, soil profile moisture will be measured to determine storage capacity of the soil. After drainage studies are completed, this treatment will be identical to Treatment 1, except that it initially will be a much wetter profile. The surface will be uncovered and vegetation introduced; this will demonstrate how fast the barrier system can recover from an extreme precipitation event or flooding event. Replication: 2 drainage lysimeters.

Material Layers

Surface - initially bare, then seeded and transplanted

0.05 to $1.55 \mathrm{~m}$ - soil backfill from McGee Ranch

1.55 - geotextile mat

1.55 to $1.95 \mathrm{~m}$ - sand and gravel layers

1.95 to $3.0 \mathrm{~m}$ - basalt riprap

Instrumentation

Neutron probe: measurements taken at depths of $0.15,0.300 .60,0.75$, $0.90,1.20,1.35$, and $1.50 \mathrm{~m}$

Gamma probe: measurements taken at depths to be determined

Tensiometers: installed at depths of $0.5,1.0$, and $1.5 \mathrm{~m}$

Thermocouples: installed at depths of $0.5,1.0$, and $1.5 \mathrm{~m}$ 



\section{INSTALLATION OF LYSIMETERS}

Construction of the FLTF lysimeters was completed during the second half of FY 1987. The empty containers were placed in a parallel configuration adjacent to each other as shown in Figure 3. After installation, the bottom and $10 \mathrm{~cm}$ of the side wall inside of each lysimeter was painted to provide a redundant seal and minimize rusting. The lysimeters were then leak tested by adding a known amount of water, waiting several days, then collecting and weighing the water in each lysimeter. This mass-balance check determined the effectiveness of the seal. After tank water retention was determined, the drainage and weighing lysimeters were filled with soil and rock materials.

The weighing lysimeters were easier to fill than backfilling the drainage lysimeters for two reasons: 1) only soil is required as backfill and 2) the weighing platform can be used to determine bulk density of the backfill as the weighing lysimeter is filled. The following steps were taken when filling the weighing lysimeters:

1. Calibrate and determine temperature sensitivity of the scales for use in engineering units and temperature correction equations.

2. Install geotextile over a $1-\mathrm{cm}$ layer of gravel that was placed to provide horizontal drainage and to create the pore-size discontinuity at the bottom of the lysimeter.

3. Conduct a final leak test of the lysimeters.

4. Position the TC, TC psychrometers, and tensiometers along the side wall and adjust to final position as soil is backfilled.

5. Sample the backfill soil for moisture water and optional particlesize analysis if needed (samples were retained for analysis).

6. Position the access wells for neutron and gamma probes and the clear plastic tubes for root observations (in lysimeters with vegetation).

7. Fill the lysimeters in lifts (incremental depths of soil) to allow sensor placement and bulk-density measurements.

8. Transplant vegetation if required. 
The drainage lysimeters were more difficult to fill because the rock layer had to be placed from 3.0 up to $1.95 \mathrm{~m}$. In addition, the backfill materials had to be weighed on an external platform scale when they were installed so that the bulk density could be determined. A front-end bucket loader and $9080-\mathrm{kg}(20,000$ lb) platform scale was used to weigh the material as it is placed in the lysimeters. Figure 6 shows a cross-section of a typical drainage lysimeter with instruments in place. The following steps were taxen when filling the drainage lysimeters:

1. Prepare materials for use in backfill (characterize rock and gravel size, sample soil for particle size and moisture).

2. Conduct a final leak test.

3. Place instrument string along the side wall of lysimeter.

4. Install the access wells through the sidewall extending $10 \mathrm{~cm}$ into rock layer.

5. Place $1.05 \mathrm{~m}$ of rock, add $0.4 \mathrm{~m}$ of sand and gravel layers, and the geotextile.

6. Backfill 10-cm lifts, place instrumentation as necessary, and measure density (repeat the process until full).

7. Transplant vegetation, if required (in fall or spring).

\section{INSTRUMENTATION REQUIREMENTS AND INSTALLATION}

Accurate measurements of drainage and other water-balance parameters are critical to the success of the FLTF in determining the effectiveness of barriers. Table 2 contains a list of parameters that will be measured at the FLTF and an estimate of the precision and accuracy associated with each measurement technique. In many cases, the precision and accuracy of the measurement technique is not available (Table 2). In those cases, we rely on experienced staff to estimate the error until better estimates of initial data sets are collected, compared with other measurements, and analyzed. Table 3 lists the expected precision for assessment of individual water-balance components (in terms of centimeters of $\mathrm{H}_{2} \mathrm{O}$ ). 
TABLE 2. List of Parameters to be Measured at the FLTF

\begin{tabular}{|c|c|c|c|}
\hline Measurement & Methods & Precision $( \pm)$ & Accuracy $( \pm)$ \\
\hline Length $(\mathrm{cm})$ & Tape & $0.1 \mathrm{~cm}$ & $0.1 \%$ of length \\
\hline \multirow[t]{2}{*}{ Mass $(g)$} & $\begin{array}{l}\text { Platformi } \\
\text { scales }\end{array}$ & $50.0 \mathrm{~g}$ & Several $\mathrm{kg}$ \\
\hline & $\begin{array}{l}\text { Lab scales } \\
(0-500 \mathrm{~g}) \\
(0.5-120 \mathrm{~kg})\end{array}$ & $\begin{array}{l}0.01 \mathrm{~g} \\
0.1 \mathrm{~g}\end{array}$ & Same as precision \\
\hline $\begin{array}{l}\text { Bulk soil } \\
\text { density }\left(\mathrm{g} / \mathrm{cm}^{3}\right)\end{array}$ & $\begin{array}{l}\text { Sample and } \\
\text { weight } \\
\text { (lab scales) }\end{array}$ & $0.05 \mathrm{~g} / \mathrm{cm}^{3}$ & $\begin{array}{l}0.1 \mathrm{~g} / \mathrm{cm}^{3} \\
\text { (function of } \\
\text { packing } \\
\text { variability) }\end{array}$ \\
\hline $\begin{array}{l}\text { Water content } \\
\text { (gravimetric) } \mathrm{g} / \mathrm{g}\end{array}$ & $\begin{array}{l}\text { Wet and oven- } \\
\text { dry weight } \\
\text { (lab scales) }\end{array}$ & $0.01 \mathrm{~g} / \mathrm{g}$ & $\begin{array}{l}\text { Subject to } \\
\text { soil } \\
\text { variability }\end{array}$ \\
\hline \multirow{2}{*}{$\begin{array}{l}\text { Water } \\
\text { (volumetric) } \\
\mathrm{cm}^{3} / \mathrm{cm}^{3}\end{array}$} & Neutron probe & $0.005 \mathrm{~cm}^{3} / \mathrm{cm}^{3}$ & $\begin{array}{l}0.01 \text { tg } 0.02 \\
\mathrm{~cm}^{3} / \mathrm{cm}^{3}\end{array}$ \\
\hline & $\begin{array}{l}\text { Gamma probe } \\
\text { (water con- } \\
\text { tent change) }\end{array}$ & $\begin{array}{l}\text { Est imated } \\
0.005 \mathrm{~cm}^{3} / \mathrm{cm}^{3}\end{array}$ & $\begin{array}{l}\text { estimated } \\
0.005 \text { to } 0.01 \\
\mathrm{~cm}^{3} / \mathrm{cm}^{3}\end{array}$ \\
\hline Temperature $\left({ }^{\circ} \mathrm{C}\right)$ & $\begin{array}{l}\text { Copper/ } \\
\text { constantan } \\
\text { thermocouple }\end{array}$ & $0.008^{\circ} \mathrm{C}$ & $0.01^{\circ} \mathrm{C}$ \\
\hline $\begin{array}{l}\text { Water potential } \\
(\text { matric) (MPa) }\end{array}$ & $\begin{array}{l}\text { Gypsum blocks } \\
\text { (AC resis- } \\
\text { tance) }\end{array}$ & $\begin{array}{l}\text { Varies from } \\
0.002 \mathrm{MPa} \text { (wet) } \\
0.2 \mathrm{MPa} \text { (dry) }\end{array}$ & $\begin{array}{l}\text { Confidence inter- } \\
\text { val of calibration } \\
\text { curve }\end{array}$ \\
\hline $\begin{array}{l}\text { Water potential } \\
\text { dry (total) } \\
\text { (MPa) }\end{array}$ & $\begin{array}{l}\text { TC psychro- } \\
\text { meter (wet } \\
\text { bulb) }\end{array}$ & $0.05 \mathrm{MPa}$ & $\begin{array}{l}\text { Confidence inter- } \\
\text { val of calibration } \\
\text { curve }\end{array}$ \\
\hline $\begin{array}{l}\text { Water potential } \\
\text { wet (total) } \\
\text { (MPa) }\end{array}$ & Tensiometers & $0.0001 \mathrm{MPa}$ & $0.0005 \mathrm{MPa}$ \\
\hline $\begin{array}{l}\text { Drainage (g or } \\
\text { equivalent } \mathrm{cm} \\
\text { of } \mathrm{H}_{2} \mathrm{O} \text { ) }\end{array}$ & Collection & $<0.0001 \mathrm{~cm}$ & $\begin{array}{l}\text { Function of } \\
\text { lysimeter design } \\
\text { and outflow } \\
\text { system }\end{array}$ \\
\hline
\end{tabular}


TABLE 3. Expected Measurement Precision for Water-Balance Components of Drainage, Storage, Evapotranspiration, and Precipitation

\begin{tabular}{|c|c|c|c|}
\hline Component & Measurement Method & $\begin{array}{l}\text { Instrument } \\
\text { Resolution }\end{array}$ & $\begin{array}{c}\text { Expected } \\
\text { Precision (cm) } \\
\end{array}$ \\
\hline \multirow[t]{2}{*}{ Drainage } & $\begin{array}{l}\text { Weigh outflow water } \\
\text { from drainage lysimeters } \\
\left.\text { (Area }=26,300 \mathrm{~cm}^{2}\right)\end{array}$ & $\begin{array}{l} \pm 10 \mathrm{~g} \text { (using } \\
\text { top-loading } \\
\text { scales) }\end{array}$ & $\begin{array}{l}0.0004 \\
\left(\text { short } \nmid f^{m}\right) \\
\pm 0.04 \\
\text { (yearly) }\end{array}$ \\
\hline & $\begin{array}{l}\text { Weigh outflow water } \\
\text { from weighing lysimeters } \\
\text { lysimeters (Area = } \\
23,104 \mathrm{~cm}^{2} \text { ) }\end{array}$ & $\begin{array}{l} \pm 10 \mathrm{~g} \text { (using } \\
\text { top-loading } \\
\text { scales) }\end{array}$ & $\begin{array}{l}0.0004 \\
\text { (short tegm) } \\
\pm 0.04(a) \\
\text { (yearly) }\end{array}$ \\
\hline \multirow[t]{2}{*}{ Storage Change } & $\begin{array}{l}\text { Calculate water content } \\
\text { using neutron probe }\end{array}$ & $0.005 \mathrm{~cm}^{3} / \mathrm{cm}^{3}$ & $\simeq 1.6^{(b)}$ \\
\hline & $\begin{array}{l}\text { Calculate water content } \\
\text { using gamma probe }\end{array}$ & $0.005 \mathrm{~cm}^{3} / \mathrm{cm}^{3}$ & $\simeq \pm 0.8^{(b)}$ \\
\hline \multirow[t]{2}{*}{ Evapotranspiration } & $\begin{array}{l}\text { Calculate the water } \\
\text { balance from measured } \\
\text { storage, precipitation, } \\
\text { and drainage change } \\
(E T=\Delta S+P+D)(e)\end{array}$ & $\begin{array}{l}\text { limited by } \\
\text { neutron probe } \\
\text { resolution in } \\
\text { calculating }\end{array}$ & $\simeq 1.6$ \\
\hline & $\begin{array}{l}\text { Calculate water } \\
\text { balance monitoring } \\
\text { the weight changes } \\
\text { of weighing lysimeter }\end{array}$ & $\begin{array}{l}50 \mathrm{~cm}^{3}(\mathrm{~g}) / \mathrm{b} \\
23,104 \mathrm{~cm}^{2}\end{array}$ & $\begin{array}{l}\sim 0.0022 \\
\text { (hourly) } \\
\sim 0.04(c) \\
\text { (monthly) }\end{array}$ \\
\hline \multirow[t]{2}{*}{ Precipitation } & $\begin{array}{l}\text { Record using a tipping } \\
\text { bucket rain gauge }\end{array}$ & $0.025 \mathrm{~cm}$ & $\sim 0.2^{(d)}$ \\
\hline & $\begin{array}{l}\text { Calculate positive } \\
\text { weight changes of the } \\
\text { weighing lysimeter } \\
\text { (ignoring ET) }\end{array}$ & $\begin{array}{l}50 \mathrm{~cm}^{3}(\mathrm{~g}) / 2 \\
23,104 \mathrm{~cm}^{2}\end{array}$ & $\begin{array}{l} \pm 0.0022(c) \\
\text { (short dura- } \\
\text { tion events) }\end{array}$ \\
\hline
\end{tabular}

(a) Uncertainty in annual drainage values resulting from possible vapor condensation effects.

(b) Uncertainty in probe cross-calibration and user error.

(c) Uncertainty in lysimeter temperature sensitivity, soil loss, and plant growth additions.

(d) Uncertainty in variability in rainfall/snowmelt, etc.

(e) $E T=$ evapotranspiration, $\Delta S=$ change in storage, $P=$ precipitation, $D=$ drainage. 


\section{INSTRUMENTATION AND MEASUREMENT TECHNIQUES}

NEUTRON PROBE

A neutron probe will be used to measure volumetric water content of soils. Calibration of the probe is sensitive to soil type, soil density, and access well material and any materials containing hydrogen (plastics, asphalt). Calibration information is collected using three calibration techniques: field calibration, wet and dry standards, and factory calibrations.

The first calibration technique is a field calibration taken at the time the access well is installed. This calibration is accomplished by measuring the water content of soil samples collected as each layer is installed. The gravimetric water content is determined by oven drying (ASTM 1985a). Measurement of the soil bulk density (oven-dry mass/unit volume) will allow the conversion of gravimetric moisture to volumetric moisture contents. The volumetric water contents from all layers are compared with probe readings taken as soon as the lysimeter is completely backfilled and a linear regression curve is developed.

The second calibration technique uses an access well centered in a large tank positioned on a scale. The scale is used to determine bulk density of the soil (i.e., $\mathrm{g} / \mathrm{cm}^{3}$ or $\mathrm{Mg} / \mathrm{m}^{3}$ ) as the tank is packed with the soil of interest at a known field water content. The soil is then wetted to near saturation and allowed to drain. Neutron probe and gravimetric measurements are made several times during this procedure, yielding a calibration curve based on several points with sufficient spread in water content.

The third calibration technique relies on factory calibrations and crosscomparisons of calibrations for various neutron probe and soil combinations. This technique is the least accurate and is only used as a backup method or a cross check for field calibrations. In general, a single neutron probe measurement will have a resolution of $\pm 0.005 \mathrm{~cm}^{3} / \mathrm{cm}^{3}$. Probe accuracy decreases between $D$ (soil surface) and $15 \mathrm{~cm}$ and between 135 and $150 \mathrm{~cm}$ (near material interfaces). Installation of the access wells is discussed in the following section. 


\section{DENSITY PROBE}

Three different gamma density probes will be used to measure soil density and water content. A surface density/moisture probe will be used during backfill of each lysimeter to measure soil density and water content. A conventional down-well density/moisture probe will be used to monitor density of the soil in the immediate vicinity around each access well located in each treatment. In addition, the radioactive source in the down-well density/moisture probe will be used with a NaI detector located in an adjacent parallel well. This arrangement will allow us to measure density in a thin slice of soil between the two wells. Density is a function of the soil mass and the water content. Because the soil density should not change significantly through time, any change in count rate should be related to water content changes. This measurement technique will be used for material near the surface and near the soil/rock interface where standard neutron probe measurements are not accurate.

The access wells used to take the density measurements will be the same access wells installed for neutron probe moisture measurement. Three wells are installed in a triangle using standard 5.08-cm aluminum pipe. The NaI detector will be positioned in one well at the same elevation as the down-well gamma probe, which can be positioned in either of the adjacent wells. The wells will extend from the surface to $10 \mathrm{~cm}$ below the soil/rock interface.

\section{TENSIOMETERS}

Tensiometers measure matric water potential directly through a hydraulic link between a pressure gauge or transducer and the soil water. This link is achieved by connecting a porous, ceramic material, which is filled with water and is in direct contact with the soil material, to a pressure gauge or transducer. As long as the ceramic material does not dewater or air does not outgas excessively from the water, the soil water potential can be measured. However, tensiometers generally fail below $-0.07 \mathrm{MPa}(-0.7$ bar). The pressure transducers used to read each tensiometer will be calibrated using hanging water columns. 


\section{THERMOCOUPLE PSYCHROMETER}

The thermocouple psychrometer (TCP) is suitable for water potential measurements at potentials less (more negative) than $-0.1 \mathrm{MPa}(-1 \mathrm{bar})$. This device is constructed from small (1 mil) thermocouple wire inside a wire screen cage. The TCP is designed so that it is cooled for a short period of time, which causes condensation of water vapor at the end of the thermocouple. A measurable voltage is generated as the condensed water evaporates and cools the thermocouple. The voltage is a function of the evaporation rate (wet bulb depression), which is, in turn, a function of the vapor pressure or total water potential (Brown and Van Haveren 1972). The calibration of the TCP is obtained from equilibration tests over known salt solutions of specified water potentials; this calibration produces voltage versus water potential curves.

\section{THERMOCOUPLES}

Thermocouples (copper/constantan) will also be used to monitor vertical and horizontal temperature gradients in selected iysimeters. Selected thermocouples will be monitored continuously with a CR7 (Campbell Scientific Inc., Logan, Utah) data logger, and remaining thermocouples will be read quarterly. Thermocouples will be checked for operation before installation. The thermocouples will not require individual calibration when used in the temperature range found in the soil. Individual calibration is not required since thermocouple junction error is much less than the measurement resolution required.

\section{TRACERS}

Water-soluble chemical and radioactive materials are often placed in soil systems to gather information on water movement in the soil profile. Generically, these studies are referred to as tracer studies. Tracers may be used to determine flow direction and magnitude or the tracer-dependent, associated hydrodynamic dispersion. Generally, tracers are used when the boundary of the system under investigation is extensive and direct measurements of water flux are impossible as in large-scale aquifer injection studies. Tracers are also used in small-scale studies in laboratory columns and lysimeters when water movement is expected to be so low as to be undetectable by any other means. 
Drainage rates in the FLTF lysimeters are expected to be low, and tracers may be needed to determine the direction and possibly the magnitude of water movement in these lysimeters. Radioactive tracers, which could be used in this facility, include tritium and deuterium at very low concentrations. These tracers move as an integral part of the water and do not suffer the complications associated with anion exclusion or cation exchange. Analysis of the tracers is expensive, requiring removal of a soil sample and subsequent analysis of the soil water fraction by liquid scintillation (tritium) or gas chromatograph/mass spectroscopy (deuterium). These tracer tests may be used in subsequent years if initial observations indicate their potential usefulness. 


\section{DESCRIPTION OF TASKS}

In addition to the installation of the lysimeters, several tasks are required to document the activities formally and to quantify the parameters that are used as inputs to models that may be calibrated against the lysimeter data. First, the site will be monitored with micrometeorological measurements to supplement those data available from the adjacent HMS. The data include, but are not limited to, onsite measurements of net radiation, wind speed, and surface and soil temperatures. Second, soil and plant characterization data will be required not only for formal documentation of the barrier design, but also for modeling purposes. Third, enhanced precipitation application will require onsite measurements of water application rates and precipitation measurements. Finally, these data will need to be archived under proper quality assurance guidelines. The expected materials, manpower, and reporting requirements needed to complete this effort are provided in the subsections that follow.

\section{MICROMETEOROLOGICAL DATA COLLECTION}

Micrometeorological data collection will be limited to those measurements not taken by the HMS. Currently, the HMS can provide hourly values of precipitation, solar radiation, air temperature, relative humidity, wind speed and wind direction, and cloud cover. Additional instruments that may be used to take micrometeorological measurements will include net radiometers and possibly infrared surface-temperature sensors.

\section{SOIL AND VEGETATION CHARACTERIZATION}

Soil samples will be collected from the McGee backfill to measure physical characteristics, such as particle size (ASTM 1985b; Gee and Bauder 1986) and water retention (Klute 1986). These samples will be collected during the installation of each lift of backfill material in each lysimeter. Additional near-surface and access-port soil samples will be collected at selected times each year to measure moisture water (ASTM 1985a) in selected lysimeters. 
Bulk-density measurements will be made using both destructive sampling (Blake and Hartge 1986) and a surface density probe during backfill of each lysimeter.

Vegetation transplanted onto the lysimeters will be monitored using nondestructive techniques. Canopy cover will be estimated using Daubenmire's method (Daubenmire 1959). Nondestructive point intercept methods will be investigated to estimate leaf area after the vegetation is established. Root growth will be observed using cameras in vertical, transparent observation tubes. Leaf diffusion resistance values for different species will be obtained using a steady-state porometer. Leaf water potential will be evaluated using a pressure bomb. If gas exchange equipment becomes available, transpiration values for the entire plant will be determined.

\section{PRECIPITATION ENHANCEMENT STUDIES}

Precipitation is applied to simulate performance under a wetter climate that might occur in the future and determine whether the barriers are effective under these conditions. In general, if the precipitation for a given location increases, a corresponding increase occurs in the number of cloudy days and the amount of vegetation growth at arid sites and, conversely, the incident radiation or evaporative demand decreases. The temperature extremes also will tend to be moderated because more energy is used in heating water vapor or is released during condensation and freezing. Simulation of wetter climates, however, is generally limited to the addition of precipitation (rain, not snow).

The simulation of increased precipitation is further limited by the practical limits of equipment and labor used to apply the extra precipitation. Ideally, a fully automated rainulator would be used to apply the extra precipitation; however, many technical difficulties (e.g., frozen pipes, valve failure, bulky equipment) exist making the full automation of precipitation additions unpractical.

Several different rainfall scenarios are possible. If the intent is to double the natural rainfalt, we must determine whether we should double the current year as it occurs (replicate timing, intensity, and amount of natural rainfall as closely as possible) or simply ensure that sufficient precipitation is added in a distributed manner during the year to reach twice the yearly 
average, which would be $32 \mathrm{~cm}$ (twice the $16 \mathrm{~cm}$ yearly average). If we use the latter application plan, a number of concerns must be addressed. For example, the first half of the year may be extremely dry, and the researcher may add moisture in amounts designed to accumulate twice the yearly average. However, if the natural rainfall during the last half of the year is well above normal, total precipitation may exceed the goal of $32 \mathrm{~cm}$.

Another variable to consider is the frequency at which supplemental moisture is added--daily, weekly, monthly, or yearly intervals. Daily and yearly frequencies are not under consideration because daily application would be too labor intensive and yearly application would not represent the typical seasonal distribution associated with precipitation at Hanford. High labor costs dictate that the precipitation be applied at weekly, biweekly, or monthly intervals. Other constraints are that the rate at which supplemental precipitation is applied cannot exceed the saturated conductivity of backfill soil yet must be fast enough to apply the water in a reasonable amount of time. We propose to supplement rainfall on a monthly interval. This rainfall will be added to double the average monthly precipitation amount. Because of inclement weather during winter months, it is possible we may fall behind in these water additions. Rainfall additions cannot be applied during freezing temperatures when the ground is covered with snow. The operational goal is to come as close as possible to the $32-\mathrm{cm}$ precipitation amount, but we may either under-apply or over-apply by as much as $4 \mathrm{~cm}$ for any given year.

The eight lysimeters receiving supplemental precipitation will be located adjacent to each other to simplify the use of the rainulator. Typical design criteria for rainulators include uniform application, droplet size, application rates, and droplet impact velocity. The rainulator used for the lysimeters will have a constant droplet size, droplet velocity, and application rate. The amount of precipitation applied will be controlled by the amount of time that the rainulator is operated. For the seventh treatment (precipitation to failure), several 100-year precipitation events will be applied in early spring or late fall to cause excess infiltration and subsequent drainage. 
MANPOWER AND MATERIAL ESTIMATES

Construction of the lysimeter facility was completed during June of 1987. Lysimeter cleaning, painting, and backfilling required 4 days per drainage lysimeter and 3 days per weighing lysimeter. Approximate (PNL and WHC) project costs related to FLTF construction for FY 1987 were $300 \mathrm{~K}$ for capital construction and $220 \mathrm{~K}$ for research staff and general materials. Table 4 has projected expenditures for the FLTF task during fiscal years 1988 through 1992.

REPORTING

Monthly reports will be used to document the progress of construction, filling, and testing of the FLTF. A document describing the as-built specifications of the lysimeter treatments wi11 be issued in FY 1988. This document will also contain initial observations of lysimeter behavior. A similar report will be published to document each year of the project.

\section{QUALITY ASSURANCE}

A quality assurance plan, OHE-2 Rev. O which was issued May 26, 1987, is in effect for this project and will be followed throughout the project. In addition to the information contained in the quality assurance (QA) plan, the data collection will be guided by the additional specific requirements of quality control and calibration information listed in Table 5 . Written procedures are being developed to inform the user of the proper operation of each instrument.

The data from measurements taken at the FLTF will be recorded and stored using several procedures. Neutron and gamma probe readings will be recorded in standard project notebooks and stored in memory on the digital readout unit. When complete measurements have been taken, the data will be transferred from the digital readout unit to the protective barriers data base. The data will be permanently stored on the project Microvax computer. 
TABLE 4. Projected Operational Expenditures for FY 1988 Through FY 1992 Work Activity

Yearly Expenditures (\$K)

Task Management

10

(meetings, monthly reports, project integration)

Site operation and maintenance (includes

equipment acquisition

Data collection

(Neutron probe, gamma probe, vegetation analysis, etc.)

Data management

(Manage Project computer, data base, QA data)

Data analysis

(Estimates of evapotranspiration drainage, and

storage change; comparison with model simulation)

Reporting

(includes reports, presentations, travel)

TOTAL

TABLE 5. Quality-Controlled Instruments: Calibration and Operation

\begin{tabular}{|c|c|c|}
\hline Instruments & Calibration & Frequency \\
\hline Data logger & User & $\begin{array}{l}\text { Before installation } \\
\text { and yearly }\end{array}$ \\
\hline Neutron probe & User & Yearly \\
\hline $\begin{array}{l}\text { Gamma probe } \\
\text { down well }\end{array}$ & User & Yearly \\
\hline $\begin{array}{l}\text { Gamma probe } \\
\text { surface }\end{array}$ & User & Yearly \\
\hline Multimeters & HEDL (a) & Yearly \\
\hline Platform scale & HEDL/user & $\begin{array}{l}\text { Before installation } \\
\text { and quarterly }\end{array}$ \\
\hline
\end{tabular}

(a) Hanford Engineering Development Laboratory. 
Vegetation measurements will be recorded in the field in the appropriate project notebooks. Observations and measurements of drainage will also be recorded in the project notebook. The data from the thermocouples, thermocouple psychrometers, and moisture blocks will be recorded and stored automatically on the data logger. The data will then be transmitted by telephone line or by radio link to an IBM PC/AT for primary analysis. These data will also be transferred to the protective barriers data base on the project Microvax computer for permanent storage. 


\section{SAFETY}

Standard PNL and WHC safety procedures for field monitoring will be followed. Neutron and gamma probes will be stored in designated locations at the FLTF and used to monitor the water content profiles in the drajnage and weighing lysimeters. A radiation work procedure has been prepared by PNL and will be followed by all staff members when using these radiation sources. If tracers are used at this facility, a work procedure will be prepared and strictly followed. Because the facility is largely underground, staff should work inside only while the ventilation fan is on; (note: the fan operates only whenever the lights are on). Periodic inspection of the underground facility will be made for rodent control to minimize damage to wiring, etc. Risk and safety forms will be prepared annually to alert PNL and WHC Safety offices of any changes in the planned activities at the FLTF site. 
.. 


\section{EXPECTED RESULTS AND CONCLUSIONS}

Information on lysimeter performance will be collected from treatments that represent a finite and limited set of environmental conditions. It is expected that after a 4- to 5-year period of testing, conclusions can be made regarding the performance of selected barrier designs. Test cases, as monitored in the lysimeters, include a wide range of conditions (e.g., precipitation, surface cover, and soil depth) so that bounding cases for barrier drainage can be evaluated. From these test cases and monitoring efforts, model calibration and validation data sets can be formulated with which to validate computer codes used to predict one-dimensional barrier performance.

The current treatments will provide information on how well the layeredsoil barrier performs, in terms of infiltration control. Observations of lysimeter performance coupled with long-term model simulations will allow optimization of the barrier design. As this optimization effort proceeds, it may be worthwhile to modify treatments in the FLTF to collect information related to specific aspects of barrier performance. Past experience with other lysimeter systems at Hanford has shown this type of research facility to be useful far beyond the original project funding or initial research effort. 



\section{REFERENCES}

ASTM (American Society for Testing and Materials). 1985a. "Standard Method for Laboratory Determination of Water (Moisture) Content of Soil, Rock, and Soil-Aggregate Mixtures." In Annual Book of ASTM Standards, Section 4: Construction, ASTM 02216-80, $\sqrt{01.04 .08, ~ A S T M, ~ P h i l a d e l p h i a, ~ P e n n s y l v a n i a . ~}$

ASTM (American Society for Testing and Materials). 1985b. "Standard Test Method for Classification of Soils for Engineering Purposes". In Annual Book of ASTM Standards, Section 4: Construction, ASTM 02487-83, Vol. 04.08, ASTM, Philadelphia, Pennsylvania.

Adams, M. R., and N. R. Wing. 1986. Protective Barrier and Warning Marker System Development Plan. RHO-RE-PL-35P, Rockwell Hanford Operations, Richland, Washington.

Blake, G. R., and K. H. Hartge. 1986. "Bulk Density." In Methods of Soil Analysis, Part l, ed. A. Kiute, pp. 363-382. American Society of Agronomy, Inc., Madison, Wisconsin.

Brown, R. W., and B. P. Van Haveren. 1972. Psychrometry in Water Relations Research. Utah Agricultural Experiment Station, Utah State University, Logan, Utah.

Daubenmire, R. 1959. "A Canopy-Coverage Method of Vegetational Analysis." Northwest Sci. 33:43-64.

Gee, G. W., and J. W. Bauder. 1986. "Particle-size Analysis." In Methods of Soil Analysis, Part 1, ed. A. Klute, pp. 383-409. American Society of Agronomy, Madison, Wisconsin.

Gee, G. W., and T. L. Jones. 1985. Lysimeters at the Hanford Site: Present Use and Future Needs. PNL-5578, Pacific Northwest Laboratory, Richland, Washington.

Klute, A. 1972. "The Determination of the Hydraulic Conductivity and Diffusivity of Unsaturated Soils." Soil Sci. 113:264-276.

Klute, A. 1986. "Water Retention: Laboratory Methods." In Methods of Soi1 Analysis. Part 1, 2nd ed. ed. A. Klute, Pp. 635-662. American Society of Agronomy, Madison, Wisconsin.

U.S. Department of Energy (USDOE). 1986. Disposal of Hanford Defense HighLevel, Transuranic and Tank Wastes. Draft Environmental Impact Statement. DOE/EIS-0113, U.S. Department of Energy, Washington, D.C.

U.S. Department of Energy-Richiand Operations Office (DOE-RL). 1986. Interim Hanford Waste Management Technology Plan. U.S. DOE-RL, Richland, Washington. 


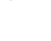




\section{DISTRIBUTION}

No. of

Copies

OFFSITE

2 DOE Technical Information Center

ONSITE

5 DOE Richland Operations Office

E. A. Bracken

J. R. Hunter

L. Olson

G. W. Rosenwald

J. J. Sutey

23 Westinghouse Hanford Company

M. R. Adams

S. Baker

L. C. Brown

R. A. Carlson

W. H. Chapman-Riggsbee

C. DeFigh-Price

K. A. Gano

C. J. Geier

W. F. Heine

W. A. Jordan

R. E. Lerch

G. G. Meade

S. J. Phillips

D. R. Pratt

J. F. Relyea

R. C. Routson

P. S. Schaus

W. W. Schulz

S. A. Wiegman

G. F. Williamson

N. R. Wing

R. D. Wojtasek

D. E. Wood
No. of

Copies

61 Pacific Northwest Laboratory

0. B. Abbey

P. A. Beedlow

P. E. Bramson

L. L. Cadwel]

M. D. Campbell

J. W. Cary

W. Conbere

J. L. Downs

D. W. Dragnich

M. J. Fayer

G. W. Gee (5)

M. J. Graham

H. A. Haerer

J. M. Hales

P. C. Hays

P. R. Heller

T. L. Jones

C. T. Kincaid

R. R. Kirkham (20)

G. V. Last

I. C. Nelson

L. E. Rogers

R. L. Skaggs

R. J. Serne

C. S. Simmons

J. A. Stott lemyre

G. P. Streile

M. E. Strong

R. Treat

W. J. Waugh

R. E. Wildung

Publishing Coordination (2)

Technical Report Files (5) 


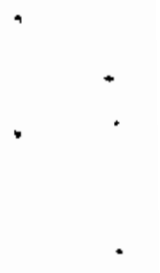

